\title{
Surface Plasmon Resonance for C-Reactive Protein Detection in Human Plasma
}

\author{
Hanen Chammem¹, Imen Hafaid ${ }^{1 *}$, Olivier Meilhac ${ }^{2,3}$, Farid Menaa ${ }^{4}$, Laurence Mora ${ }^{5}$, \\ Adnane Abdelghani ${ }^{1}$ \\ ${ }^{1}$ Carthage University, Nanotechnology Laboratory, National Institute of Applied Science and Technology, \\ Charguia, Tunisia \\ ${ }^{2}$ INSERM UMR698, Paris, France \\ ${ }^{3} \mathrm{AP}-\mathrm{HP}$, Bichat Stroke Center, Paris, France \\ ${ }^{4}$ Department of Pharmaceutical Sciences and Nanomedicine, Fluorotronics USA, Inc., San Diego, USA \\ ${ }^{5}$ Université Paris 13, Sorbonne Paris Cité, Villetaneuse, France \\ Email: ${ }^{*}$ imen haf@yahoo.fr
}

Received 13 April 2014; revised 28 May 2014; accepted 21 June 2014

Copyright ( 2014 by authors and Scientific Research Publishing Inc.

This work is licensed under the Creative Commons Attribution International License (CC BY).

http://creativecommons.org/licenses/by/4.0/

(c) (i) Open Access

\section{Abstract}

In this work, we describe an approach of detecting biomarkers by Surface Plasmon Resonance imaging (SPRi) technique in real samples. Two C-Reactive Protein (CRP)-antibody immobilization methods were used: The first method was based on direct physisorption of CRP-antibody onto gold surface; the second one was based on oriented CRP-antibody with protein G intermediate layer. The two developed immunosensors were tested against CRP antigen in phosphate buffer saline solution with the SPRi technique. The response of the developed immunosensors was reproducible and stable. The detection limit of $10 \mathrm{pg} \cdot \mathrm{mL}^{-1}$ and $50 \mathrm{pg} \cdot \mathrm{mL}^{-1} \mathrm{CRP}$-antigen was observed with and without protein $G$ respectively with this technique. Moreover, the developed SPRi immunosensor was used for CRP-antigen detection in human plasma. A detection limit of $5 \mathbf{~ n g} \cdot \mathbf{m L}^{-1}$ and $10 \mathrm{ng} \cdot \mathrm{mL}^{-1}$ was obtained with and without protein $\mathrm{G}$ respectively. These obtained results were compared to those obtained with QCM (Quartz Crystal Microbalance) and Enzyme-Linked Immunosorbent Assay (ELISA) techniques.

\section{Keywords}

C-Reactive Protein, Protein G, Surface Plasmon Resonance Imaging, Human Plasma

\footnotetext{
${ }^{*}$ Corresponding author.

How to cite this paper: Chammem, H., Hafaid, I., Meilhac, O., Menaa, F., Mora, L. and Abdelghani, A. (2014) Surface Plasmon Resonance for C-Reactive Protein Detection in Human Plasma. Journal of Biomaterials and Nanobiotechnology, 5, 153-158. http://dx.doi.org/10.4236/jbnb.2014.53018
} 


\section{Introduction}

C-reactive protein (CRP) is a protein present in plasma and is one of the most expressed proteins in acute phase inflammation cases, being a known biomarker of inflammatory states [1]. Detection and quantification of CRP in an easy, cheap, and fast way can improve clinical diagnostics in order to prevent serious inflammatory states [2]. The detection of this protein has been studied by various traditionals techniques such as radial immunodiffusion (RID), Radio-Immuno-Assay (RIA), Immuno-Nephelometry (IN), Immuno-Turbidimetry (IT), ImmunoFluorescence (IF), Immuno-Chemiluminescence (IC) and Standard Enzyme Immunoassay (SEI) [3]. The limit of detection of these assays ranges between 0.1 and $0.2 \mu \mathrm{g} \cdot \mathrm{mL}^{-1}$. Recently, an impedance spectroscopy study on gold electrode $\left(0.16 \mathrm{~cm}^{2}\right.$ surface) was performed to detect CRP-antigen and a detection limit of $100 \mathrm{pg} \cdot \mathrm{mL}^{-1}$ was attained [4].

In this work, and in order to improve the CRP detection limit for clinical use, a new approach was employed based on the excitation of surface plasmon resonance on functionalized electrode with 16 gold spots. The 16 gold spots can be functionalized with anti-CRP antibody and used for CRP-antigen detection in PBS and human serum. The surface plasmon resonance technique is becoming an attractive optical tool to characterize biomaterial films, thus, allowing transduction of biorecognition events at the respective surfaces [5]-[7].

Two anti-CRP immobilization methods were used: 1) the simple and non time-consuming physical adsorption method and 2) the oriented immobilization antibody method. The obtained detection limits were comparable with those obtained with QCM and ELISA technique in human plasma using doped magnetic core-shell [8].

\section{Experimental Section}

\subsection{SPR Instrumentation}

This work was carried using the SPR imager ${ }^{\circledR}$ II (from GWC Technologies, USA) with excitation wavelength of $850 \mathrm{~nm}$. For surface plasmon resonance excitation, a prism with refractive index of 1.7 was used. The SPR set-up was designed for analysis of molecular interactions in an array format with 16 gold spots (1 gold spot has a surface of $0.004 \mathrm{~cm}^{2}$ ) deposited on glass substrate. The resonance angle was determined according to the minimum reflectivity signal and fixed for all the measurements. A CCD (Couple Charge Device) camera simultaneously captures all data for all the gold spots and converts the reflectivity changes to pixels data (see Figure 1).

The entire gold spot was exposed to the same analyte using the $1 \mathrm{~mL}$ flow cell. Thereafter, the 16 gold spots was divided in two independent compartments by using a polydimethylsiloxane (PDMS) gasket chamber: eight gold spots functionalized with protein $\mathrm{G}$ and the others without. The substrate were washed with ethanol and inserted into the SPRi and all measurements were performed with PBS buffer at room temperature. The SPR signal was recorded upon injection of CRP-antigen. More details on SPR phenomenon can be found in reference [9].

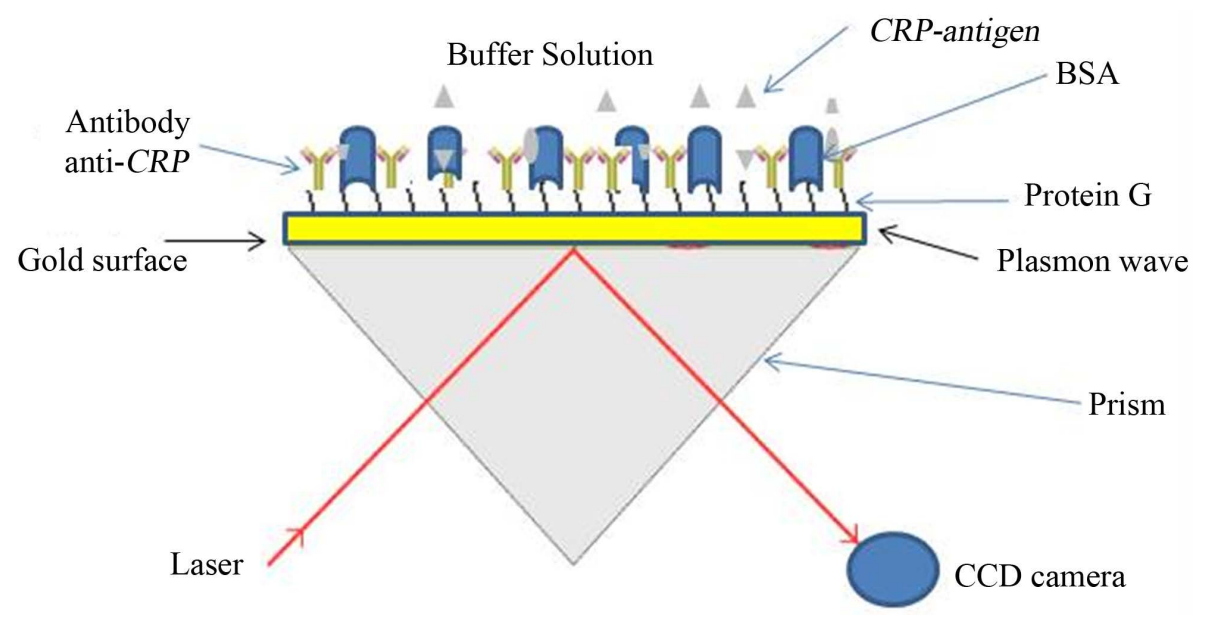

Figure 1. SPR imaging set-up. 


\subsection{Antibody and Consumables}

Bovine Serum Albumine $\left(0.45 \mathrm{mg} \cdot \mathrm{L}^{-1}\right)$, anti-CRP antibodies, purified CRP, protein G, anti-Rabbit IgG, antigenrabbit were purchased from Sigma Aldrich (France). The buffer solution used for all experiments was phosphate buffered saline (PBS) containing $140 \mathrm{mM} \mathrm{NaCl}, 2.7 \mathrm{mM} \mathrm{KCl}, 0.1 \mathrm{mM} \mathrm{Na} \mathrm{HPO}_{4}, 1.8 \mathrm{mM} \mathrm{KH}_{2} \mathrm{PO}_{4}(\mathrm{pH}=7)$. All reagents were of analytical grade and ultrapure water (resistance $18.2 \mathrm{M} \Omega \cdot \mathrm{cm}^{-1}$ ) produced by a MilliporeMilli-Q system was used.

\subsection{Physisorption and Oriented Antibody}

We used physisorption technique as a simple method for antibody immobilization for CRP-detection. This technique was simple and rapid and not requires any time consuming procedure, like thiol or silane treatment. The anti-CRP was deposited (concentration: $20 \mu \mathrm{g} \cdot \mathrm{mL}^{-1}$ ) on the seven cleaned gold spots and kept one hour at room temperature. In the second step, the gold spots were treated with $0.1 \%$ BSA solution for 30 min to block the free spaces.

For the oriented antibody, protein $\mathrm{G}$ was used as fellow: a drop of protein $\mathrm{G}$ (concentration $40 \mu \mathrm{g} \cdot \mathrm{mL}^{-1}$ ) was immobilized on the others seven gold spots during 2 hours of incubation at room temperature. The gold spots were dried with nitrogen, and then a $20 \mu \mathrm{g} \cdot \mathrm{mL}^{-1}$ anti-CRP was deposited on the gold surface for 1 hour at room temperature. Finally, the gold spots were treated with $0.1 \%$ BSA solution for 30 min to block the free spaces.

Two gold spots (one in each compartment) were used for negative test with anti-Rabbit IgG. For biosensing application, CRP-antigen at different concentrations was injected in the cell at room temperature (Figure 2).

\subsection{SPRi Detection in Human Plasma from Patient}

Plasma sample from a patient with coronary artery disease (Hopital Bichat, Paris, France) containing known concentrations of CRP-antigen were used for SPRi measurement (initial concentrations, assessed by classical particle-enhanced immunonephelometry: patient \#1: $1.3 \mu \mathrm{g} \cdot \mathrm{mL}^{-1}$ ). The SPR signal was recorded upon injection of CRP-antigen diluted in PBS.

\section{Results and Discussion}

\subsection{Detection of CRP-Antigen with SPR Imaging}

The surface plasmon set-up was carried for two types of gold microelectrode surfaces: gold surface with immobilized antibody without protein $\mathrm{G}$ and gold surface with immobilized antibodies with protein G. The SPR signal versus time was recorded and shown in Figure 3. The SPR signal increase after CRP-antigen injection was due to the specific recognition by the anti-CRP.

This recognition induces a thin layer deposition (thickness increase), which leads to a resonance angle variation at the interface. The same behaviour was observed in the case of gold surface without protein G. These results show that the biosensor based on oriented CRP-antibody with protein G allows SPR signal amplification and a better limit detection in comparison with the results obtained without protein G. The antibody orientation and binding to protein $\mathrm{G}$ improves the performance of the immunosensor, since the resulting binding capacity of the antibody is directly dependent on the surface density of protein $G$ [10]. Thus, by using the protein $G$ as an intermediate layer in the first step, the sensitivity of the immunosensor is increased.

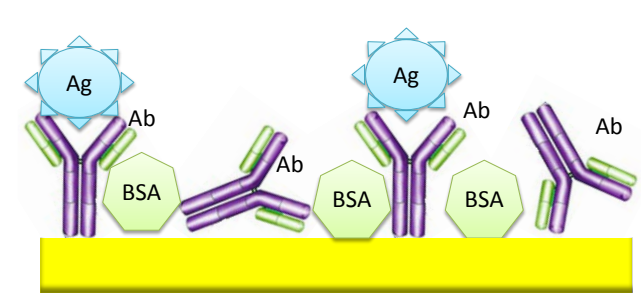

(a)

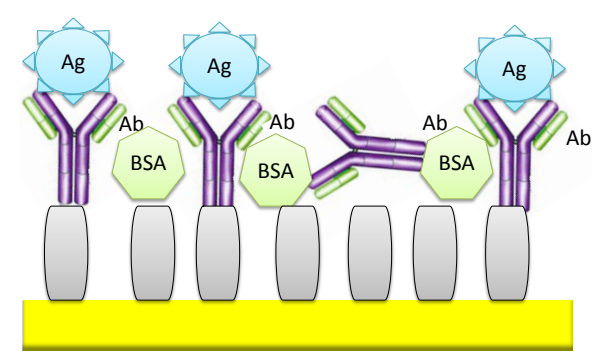

(b)

Figure 2. Biosensors configuration: (a) Without protein G; (b) With protein G. 


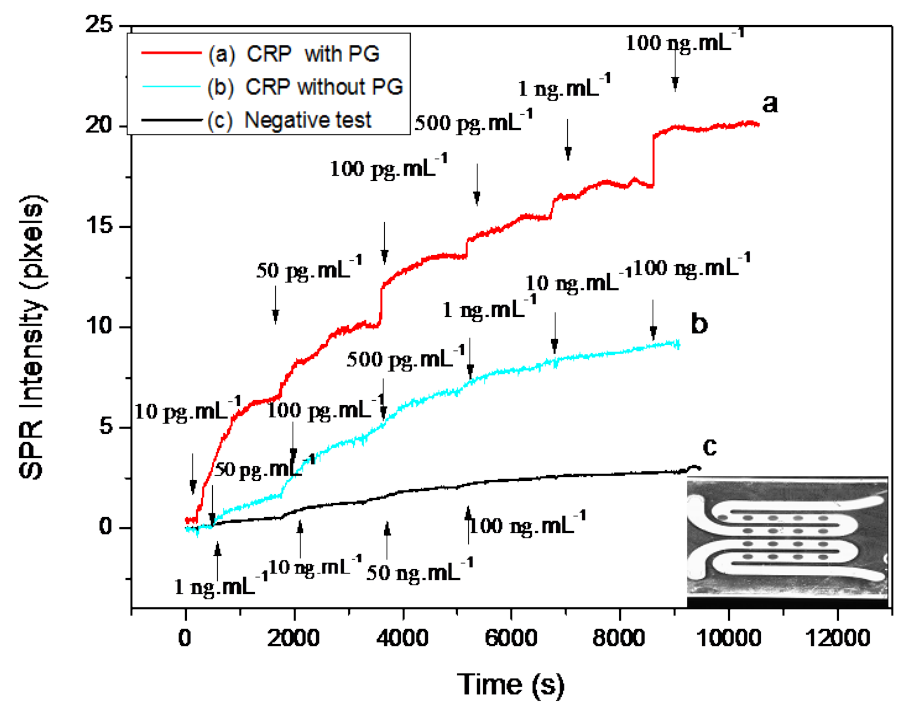

Figure 3. SPRi signal versus time for various concentrations of CRP antigen: (a) With protein G; (b) Without protein G; (c) Negative test. Gold spots (down, right).

The negative control was obtained after different injection of rabbit-antigen to the gold spots coated only with anti-CRP antibody. Figure 3(c) shows an SPR signal constant because no interaction between the rabbit-antigen and anti-CRP antibody occurred.

In order to obtain the calibration data set, the values of SPR signal variation versus the CRP-antigen concentrations of the functionalized gold surface (with and without protein $\mathrm{G}$ ) were plotted in Figure 4.

The response is linear and a detection limit of $10 \mathrm{pg} \cdot \mathrm{mL}^{-1}$ and $50 \mathrm{pg} \cdot \mathrm{mL}^{-1} \mathrm{CRP}$-antigen was obtained with and without protein $\mathrm{G}$ respectively. The reproducibility was tested against five substrates prepared in the same conditions at room temperature. Moreover, these detection limits are better than those reported by Meyer et al. and Vermeeren et al. [11] [12].

\subsection{SPRi Detection in Human Plasma from Patient}

The detection of CRP-antigen in human plasma was performed with impedance spectroscopy [4]. In this part, we performed the CRP-antigen detection from human plasma sample with SPRi technique. A different concentration (100 $\left.\mathrm{pg} \cdot \mathrm{mL}^{-1}, 1 \mathrm{ng} \cdot \mathrm{mL}^{-1}, 5 \mathrm{ng} \cdot \mathrm{mL}^{-1}, 10 \mathrm{ng} \cdot \mathrm{mL}^{-1}, 100 \mathrm{ng} \cdot \mathrm{mL}^{-1}, 150 \mathrm{ng} \cdot \mathrm{mL}^{-1}, 200 \mathrm{ng} \cdot \mathrm{mL}^{-1}\right)$ was obtained after dilution in PBS in order to improve detection in the linear range (Figure 5).

The obtained curves show the SPRi signal versus time after CRP-antigen injection in the microfluidic cell. A detection limit of $5 \mathrm{ng} \cdot \mathrm{mL}^{-1}$ and $10 \mathrm{ng} \cdot \mathrm{mL}^{-1}$ was obtained with the immunosensor with and without protein $\mathrm{G}$ intermediate layer respectively. The limit detection was better in PBS due to the interfering proteins in Human plasma. We compare in Table 1 the sensitivity of the SPRi immunsensor for CRP-detection in Human plasma with and without protein $\mathrm{G}$ intermediate layer.

The surface plasmon signal in human plasma was better using protein $G$ intermediate layer due to the better antibody orientation, which confirm the results in PBS. The advantages of oriented immobilization of biologically active protein $\mathrm{G}$ are good steric accessibilities of active binding sites of the antibody and increased stability and sensitivity of the immunosensor [13]. The obtained results were better those obtained with QCM (Quartz Crystal Microbalance) and ELISA techniques in human plasma using doped magnetic core-shell [8].

\section{Conclusion}

In this work, we describe an approach of detecting biomarkers by surface plasmon resonance imaging technique. Two CRP-antibody immobilization methods were used to enhance the sensitivity of the immunosensors. The two developed immunosensors were tested against CRP antigen in phosphate buffer saline solution and in Human plasma. The use of protein $G$ intermediate layer increases the binding capacity of the antibody which al- 


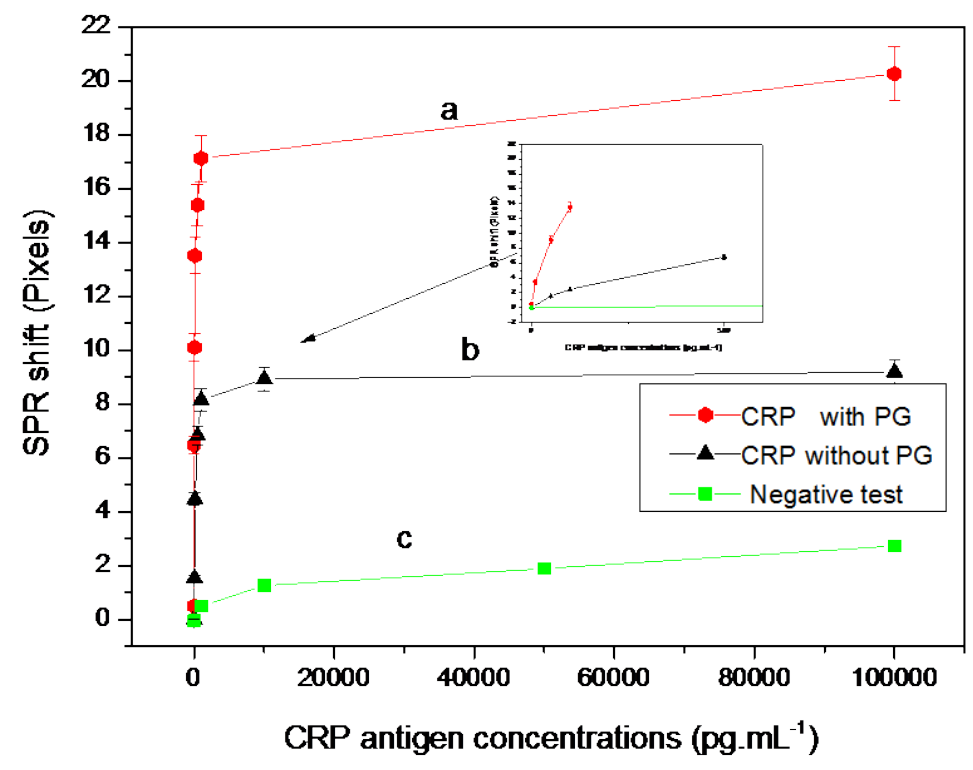

Figure 4. Calibration curve of SPR signal: (a) With protein G; (b) Without protein G; (c) Negative test. Curves for the linear part (figure inside).

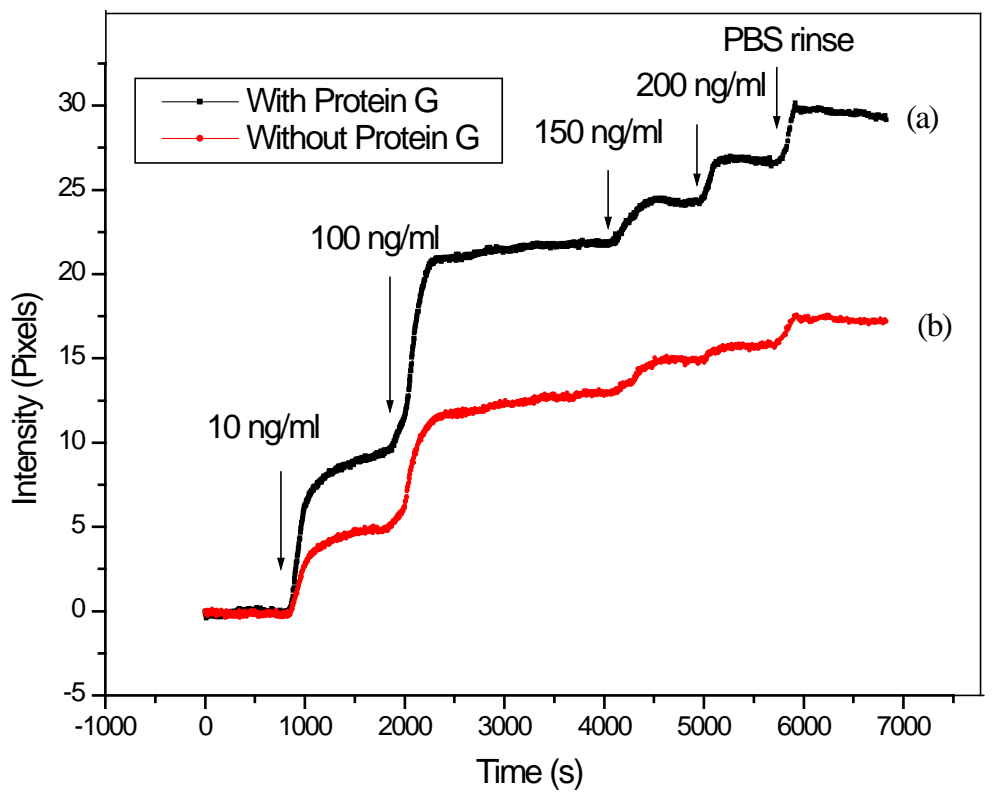

Figure 5. SPRi signal versus time for various concentrations of CRP antigen in human plasma: (a) With protein G; (b) Without protein G.

Table 1. The sensitivity of the SPRi immunosensors for CRP detection in human plasma without and with protein $\mathrm{G}$.

\begin{tabular}{cccc}
\hline CRP-antigen concentrations & $5 \mathrm{ng} \cdot \mathrm{mL}^{-1}$ & $10 \mathrm{ng} \cdot \mathrm{mL}^{-1}$ & $100 \mathrm{ng} \cdot \mathrm{mL}^{-1}$ \\
\hline SPRi signal in human plasma without protein G & No detected & 4.7 pixels & 12.8 pixels \\
SPRi signal in human plasma with protein G & 3.8 pixels & 9.1 pixels & 21.7 pixels \\
\hline
\end{tabular}

lows higher immunosensor sensitivity. The SPRi technique can be used for real-time quantification of the CRPlevels for diagnostic applications. 


\section{References}

[1] Ramadan, M., Shrive, A., Holden, D., Miles, D., Volanakis, J., Delucas, L. and Greenhough, T. (2002) Development of a Disposable Potentiometric Antibody Immobilized ZnO Nanotubes Based Sensor for the Detection of C-Reactive Protein. Acta Crystallogr, 58, 992-997. http://dx.doi.org/10.1016/j.snb.2012.03.083

[2] Sklavou, R., Karavanaki, K., Critselis, E., Kossiva, L., Giannaki, M., Tsolia, M., Papadakis, V., Papargyri, S., Vlachou, A., Karantonis, F., Gourgiotis, D. and Polychronopoulou, S. (2012) Variation of Serum C-Reactive Protein (CRP) over Time in Pediatric Cancer Patients with Febrile Illness and Its Relevance to Identified Pathogen. Clinical Biochemistry, 45, 1178-1182. http://dx.doi.org/10.1016/j.clinbiochem.2012.07.088

[3] Parra, M.D., Tuomola, M., Cabezas-Herrera, J. and Ceron, J.J. (2005) Use of a Time-Resolved Immunofluorometric Assay for Determination of Canine C-Reactive Protein Concentrations in Whole Blood. American Journal of Veterinary Research, 66, 62-66.

[4] Hafaid, I., Chammem, H., Abdelghani, A., Ait, E., Feldman, L., Meilhac, O. and Mora, L. (2013) Supported Protein G on Gold Electrode: Characterization and Immunosensor Application. Talanta, 116, 84-90. http://dx.doi.org/10.1016/j.talanta.2013.04.059

[5] Woodbury, R.G., Wendin, C., Clendenning, J., Melendez, J., Elkind, J., Bartholomew, D., Brown, S. and Furlong, C.E. (1998) Construction of Biosensors Using a Gold-Binding Polypeptide and a Miniature Integrated Surface Plasmon Resonance Sensor. Biosensors \& Bioelectronics, 13, 1117-1126. http://dx.doi.org/10.1016/S0956-5663(98)00060-8

[6] Vikinge, T.P., Askendal, A., Liedberg, B., Lindahl, T. and Tengvall, P. (1998) Immobilized Chicken Antibodies Improve the Detection of Serum Antigens with Surface Plasmon Resonance (SPR) (SPR). Biosensors \& Bioelectronics, 13, 1257-1262. http://dx.doi.org/10.1016/S0956-5663(98)00085-2

[7] Campagnolo, C., Meyers, K.J., Ryan, T., Atkinson, R.C., Chen, Y.T., Scanlan, M.J., Ritter, G., Old, L.J. and Batta, C.A. (2004) Real-Time, Label-Free Monitoring of Tumor Antigen and Serum Antibody Interactions. Journal of Biochemical and Biophysical Methods, 61, 283-298. http://dx.doi.org/10.1016/j.jbbm.2004.05.006

[8] Gan, N., Xiong, P., Wang, J., Li, T., Hu, F., Cao, Y. and Zheng, L. (2013) A Novel Signal-Amplified Immunoassay for the Detection of C-Reactive Protein Using HRP-Doped Magnetic Nanoparticles as Labels with the Electrochemical Quartz Crystal Microbalance as a Detector. Journal of Analytical Methods in Chemistry, 2013, 8 p. http://dx.doi.org/10.1155/2013/482316

[9] Baccar, H., Mejri, M.B., Hafaid, I., Ktari, T., Aouini, M. and Abdelghani, A. (2010) Surface Plasmon Resonance Immunosensor for Bacteria Detection. Talanta, 82, 810-814. http://dx.doi.org/10.1016/j.talanta.2010.05.060

[10] Löfås, S. (2007) Biacore-Creating the Business of Label-Free Protein-Interaction Analysis. In: Marks, R.S., Eds., Handbook of Biosensors and Biochips, Vol. 1, John Wiley \& Sons, Chichester, 1261-1272.

[11] Meyer, M.H.F., Hartmann, M. and Keusgen, M. (2006) SPR-Based Immunosensor for the CRP Detection-A New Method to Detect a Well Known Protein. Biosensors and Bioelectronics, 21, 1987-1990. http://dx.doi.org/10.1016/j.bios.2005.09.010

[12] Vermeeren, V., Grieten, L., Vanden Bon, N., Bijnens, N., Wenmackers, S., Janssens, S.D., Haenen, K., Wagner, P. and Michiels, L. (2011) Impedimetric, Diamond-Based Immmunosensor for the Detection of C-Reactive Protein. Sensors and Actuators, 157, 130-138. http://dx.doi.org/10.1016/j.snb.2011.03.037

[13] Turková, J. (1999) Oriented Immobilization of Biologically Active Proteins as a Tool for Revealing Protein Interactions and Function. Journal of Chromatography B: Biomedical Sciences and Applications, 722, 11-31. http://dx.doi.org/10.1016/S0378-4347(98)00434-4 
Scientific Research Publishing (SCIRP) is one of the largest Open Access journal publishers. It is currently publishing more than 200 open access, online, peer-reviewed journals covering a wide range of academic disciplines. SCIRP serves the worldwide academic communities and contributes to the progress and application of science with its publication.

Other selected journals from SCIRP are listed as below. Submit your manuscript to us via either submit@scirp.org or Online Submission Portal.
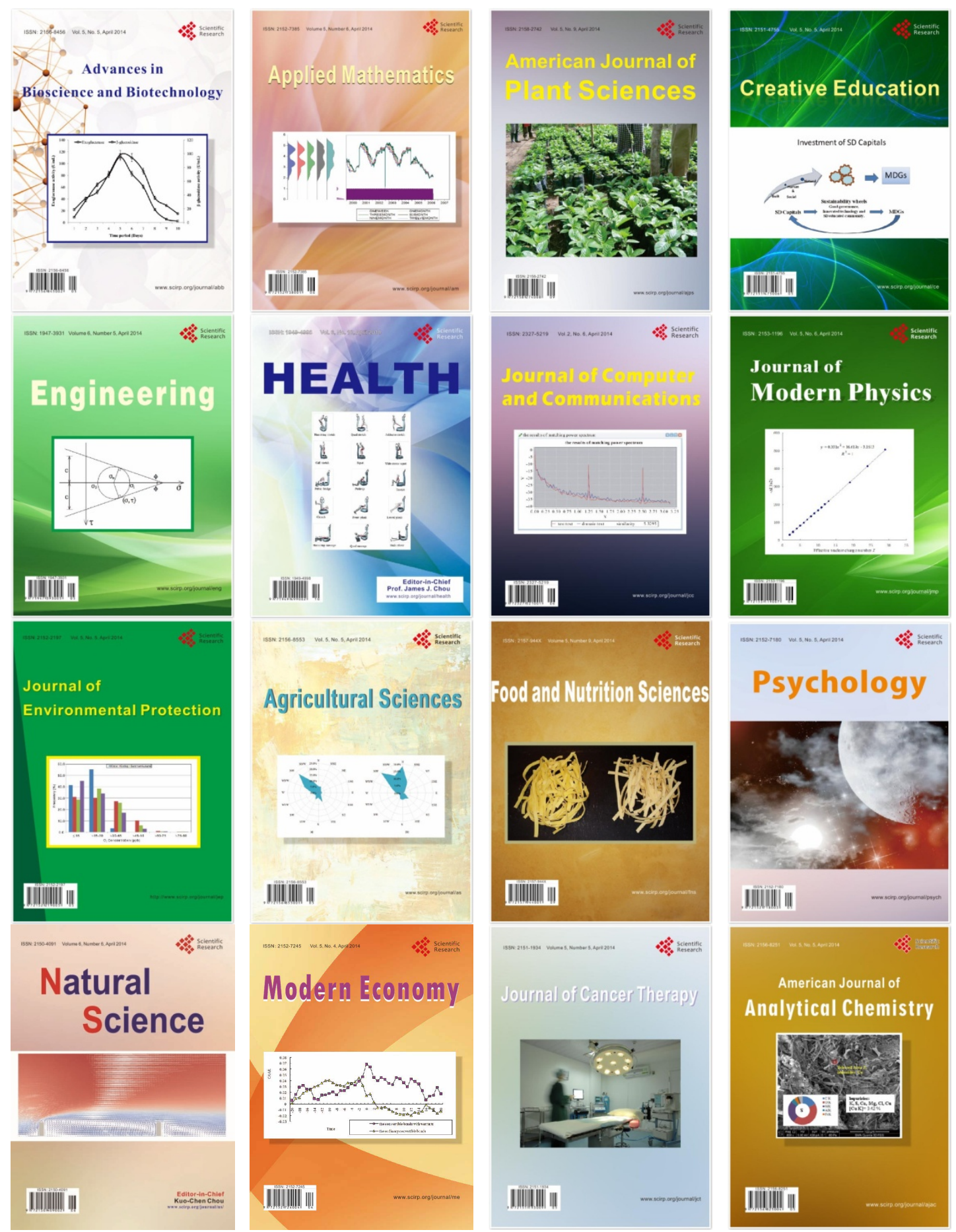